\title{
A new species of Cruzia (Ascaridida; Kathlanidae) parasitizing Salvator merianae (Squamata, Teiidae) from the Atlantic forest in Brazil
}

\author{
Uma nova espécie de Cruzia (Ascaridida; Kathlanidae) parasitando \\ Salvator merianae (Squamata, Teiidae) de Mata Atlântica no Brasil \\ Fabiano Matos Vieira ${ }^{1,2^{*}}$ (1D; Paula Araujo Gonçalves ${ }^{1,2}$; Sueli de Souza Lima ${ }^{3}$; \\ Bernadete Maria de Sousa4; Luís Cláudio Muniz-Pereira ${ }^{1,2}$ \\ ${ }^{1}$ Laboratório de Helmintos Parasitos de Vertebrados, Instituto Oswaldo Cruz - IOC, Fundação Oswaldo Cruz - FIOCRUZ, \\ Rio de Janeiro, RJ, Brasil \\ ${ }^{2}$ Programa de Pós-graduação em Biodiversidade e Saúde - PPGBS, Instituto Oswaldo Cruz - IOC, Fundação Oswaldo Cruz \\ - FIOCRUZ, Rio de Janeiro, RJ, Brasil \\ ${ }^{3}$ Laboratório de Taxonomia e Ecologia de Helmintos "Odile Bain", Universidade Federal de Juiz de Fora - UFJF, Campus \\ Universitário, Juiz de Fora, MG, Brasil \\ ${ }^{4}$ Laboratório de Herpetologia-Répteis, Departamento de Zoologia, Universidade Federal de Juiz de Fora - UFJF, Campus \\ Universitário, Juiz de Fora, MG, Brasil
}

How to cite: Vieira FM, Gonçalves PA, Lima SS, Sousa BM, Muniz-Pereira LC. A new species of Cruzia (Ascaridida; Kathlanidae) parasitizing Salvator merianae (Squamata, Teiidae) from the Atlantic forest in Brazil. Braz J Vet Parasitol 2020; 29(1): e018519. https://doi.org/10.1590/S1984-29612019111

\begin{abstract}
Cruzia lauroi sp. nov. is described from Salvator merianae (Duméril \& Bibron, 1839) (Squamata; Teiidae). The new species differs from all previously described species through several morphological characteristics: number of tooth like structures per row in the inner pharynx; and presence of unpaired papillae on the anterior border of the cloacal aperture. However, Cruzia lauroi sp. nov. is closest to C. tentaculata (Rudolphi, 1819), through having similar distribution of male caudal papillae, unpaired pre-cloacal papillae and females with an pre-equatorial vulva. Cruzia lauroi sp. nov. differs from C. tentaculata regarding smaller total body length of individuals, higher number of tooth like structures per row in the pharynx, greater size of diverticulum, smaller size of spicules and a more anterior vulva than in C. tentaculata; and the males do not have caudal alae. Cruzia mazza, C. travassosia, C. mexicana and C. testudines were considered to be species inquirendae, because their descriptions need more detailed taxonomic studies.
\end{abstract}

Keywords: Cruzia lauroi sp. nov., lizard, new species, Salvator merianae, Brazil.

\section{Resumo}

Cruzia lauroi sp. nov. é uma nova espécie descrita em Salvator merianae (Duméril \& Bibron, 1839) (Squamata; Teiidae). Essa nova espécie difere de todas as espécies descritas anteriormente por diferentes características morfológicas: pelo número de dentes por coluna longitudinal interna na faringe; pela presença de papila ímpar na borda anterior da cloaca. Entretanto, Cruzia lauroi sp. nov. possui similaridades com C. tentaculata (Rudolphi, 1819), por ter distribuição semelhante das papilas caudais dos machos, por possuir papila pré-cloacal ímpar e por possuir fêmeas com vulva préequatorial. Cruzia lauroi sp. nov. se difere de $C$. tentaculata em relação ao menor comprimento total do corpo dos indivíduos, pelo maior número de dentes por coluna longitudinal interna na faringe; pelo maior tamanho de divertículo; pelo menor tamanho de espículos; por possuir fêmeas com vulva mais próxima a extremidade anterior do que observado em fêmeas de $C$. tentaculata; e pelos 
machos não possuírem asa caudal. Cruzia mazza, C. travassosia, C. mexicana e C. testudines foram consideradas species inquirendae, pelo fato de suas descrições necessitarem de maior detalhamento taxonômico.

Palavras-chave: Cruzia lauroi sp. nov., lagartos, nova espécie, Salvator merianae, Brasil.

\section{Introduction}

Nematodes of the genus Cruzia Travassos, 1917, have been reported to inhabit the large intestine of amphibians, reptiles and, especially, mammals (Ruiz, 1947; Lent \& Freitas, 1948; Ubelaker \& Younus, 1965; Adnet et al., 2009). Until the current study, this genus included 12 nominal species that occur in North, Central and South America (Ruiz, 1947; Lent \& Freitas, 1948; Wahid, 1964; Costa, 1965; Ubelaker \& Younus, 1965; Adnet et al., 2009). However, some species of this genus need more detailed taxonomic studies and need to be re-evaluated.

In reptiles of the Neotropical region, three species of Cruzia have been reported: Cruzia rudolphii Ruiz, 1947; C. tentaculata (Rudolphi, 1819); and Cruzia travassosia Khalil \& Vogelsang, 1932 (Ruiz, 1947; Lent \& Freitas, 1948; Baker, 1987; Ávila et al., 2008; 2010; Ávila \& Silva, 2010). However, most of these reports do not provide any morphological or morphometric data on the species. Cruzia fulleborni Khalil and Vogelsang, 1930, was reported by Ávila \& Silva (2010) to be a parasite of Tupinambis teguixin (Linnaeus, 1758) (Squamata; Teiidae) (= Salvator merianae) from Argentina and Paraguay. It was transferred to the genus Schizobucca Schuurmans-Stekhoven Jr., 1950 (Ascaridida; Kathlanidae) by Schuurmans-Stekhoven (1950).

This study describes a new species of Cruzia parasitizing Salvator merianae (Duméril \& Bibron, 1839) (Squamata; Teiidae), from the Atlantic forest biome region in the state of Minas Gerais, Brazil.

\section{Materials and Methods}

The nematodes were collected from the large intestine of one specimen of $S$. merianae that

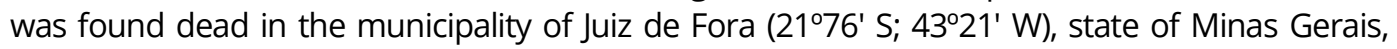
Brazil. This lizard was identified based on Peters et al. (1986) and was deposited in the Coleção Herpetologica da Universidade Federal de Juiz de Fora - Repteis (CHUFJF - Repteis 1488), Universidade Federal de Juiz de Fora, state of Minas Gerais, Brazil.

Living parasites were fixed in $4 \%$ hot formalin and were kept in this for 15 days. After this period, they were conditioned in $70^{\circ} \mathrm{GL}$ ethanol for morphological studies. For species identification, 20 adult nematodes were separated for analysis. The specimens were clarified in Amann's lactophenol, mounted on temporary slides and analyzed under an Olympus BX-41 microscope equipped with drawing tube and micrometric ocular lens, in the Laboratorio de Helmintos Parasitos de Vertebrados of the Instituto Oswaldo Cruz, FIOCRUZ, Rio de Janeiro, Brazil. All measurements are given in micrometers as ranges.

The specimens were identified to genus level in accordance with Chabaud (1978). The identification key of species of Cruzia was elaborated from the original descriptions of the species of this genus or studies of revision of these species. Holotype, allotype and paratypes were deposited in the Helminthological Collection of the Instituto Oswaldo Cruz (CHIOC), FIOCRUZ, RJ, Brazil. 


\section{Results}

\section{Description}

Cruzia lauroi sp. nov. (Figure 1)

General morphology. The parasites are long, straight and thick. The mouth is surrounded by three well-formed lips (Figure 1B). The shape of the lips is pyramidal, with triangular spaces left between each of them (Figure 1B). The dorsal lip has a pair of lateral papillae, and the two latero-ventral lips have only one papilla and one amphid on each (Figure 1B). One pair of tiny tooth like structures is located at the inner margin of each lip (Figure 1B). The pharynx is lined with a cuticle that has three columns with two parallel lines of tooth like structures each, that look like a saw, which project into the lumen (Figures 1A, B). The intestinal diverticulum extends anteriorly beyond the esophageal bulb (Figure 1A). Lateral alae are absent.

Males (Based on 10 adult specimens). Body elongated. Total body length $6.60-8.82 \mathrm{~mm}$ (7.41 $\pm 0.98 \mathrm{~mm})$, maximum width 337-375 (362.5 \pm 35.94). Pharynx 97-150 (125 \pm 26.46$)$ long. Esophagus 1.31-1.95 mm (1.63 $\pm 0.29 \mathrm{~mm})$ long and 80-150 (117.5 \pm 31.22$)$ wide, bulb 200-310 (270 \pm 60.83$)$ long and 200-300 (253 \pm 50.33) wide. Nerve ring 260-480 (375 \pm 90$)$ and excretory pore 770-930 (840 \pm 93.1$)$ from cephalic end. Intestinal diverticulum 550-850 (775 \pm 150 ) long. Posterior region ventrally curved, becomes narrower posterior to cloacal aperture and almost cylindrical in the posterior third, ending as a conical tip shape (Figure 1C). Cloacal aperture 140-250 (197.5 \pm 45$)$ from posterior end. Caudal region shows 10 pairs of sessile papillae symmetrically ventro-laterally located, three large pre-cloacal papillae, three ad cloacal papillae and four post-cloacal papillae, and one unpaired papillae at the anterior border of cloacal aperture (Figures 1C-E). Gubernaculum with triangular shape (Figure 1D) 130-180 (155 \pm 20.82) long. Spicules similar, long and robust (Figures 1C, D), 600-750 (648 \pm 63.06$)$ long.

Females (Based on 10 adult specimens). Body elongated. Total body length 8.21-9.75 mm $(8.89 \pm 0.66 \mathrm{~mm})$, maximum width 370-450 (420 \pm 34.64$)$. Pharynx 140-200 (165 \pm 25.17$)$ long. Esophagus 1.56-2 mm (1.87 $\pm 0.22 \mathrm{~mm})$ long and 120-150 (133 \pm 12.88$)$ wide, bulb 270-330 (302 \pm 25$)$ long and 280-330 (307.5 \pm 22.17$)$ wide. Nerve ring 260-420 (370 \pm 77.89$)$ and excretory pore 870-920 (955 \pm 55.1) from cephalic end. Intestinal diverticulum 470-980 (725 \pm 294.45$)$ long. Vulva pre-cloacal, 1.71-2.17 mm (1.95 \pm 0.23$)$ from cephalic end. Eggs not observed, adult females, but with eggs not yet formed. Posterior end sharply conical (Figure 1F), tail 610-920 (730.5 \pm 130.48$)$ long.

\section{Taxonomic summary}

Type-host: Salvator merianae (Duméril \& Bibron, 1839) (Squamata, Teiidae) (Argentine Black and White Tegu).

Locality: Municipality of Juiz de Fora $\left(21^{\circ} 76^{\prime} \mathrm{S}, 4^{\circ} 21^{\prime} \mathrm{W}\right)$, state of Minas Gerais, Brazil.

Site of infection: Large intestine.

Type-material: Holotype male (CHIOC 38781a), allotype female (CHIOC 38781b), 2 male and 2 female paratypes (CHIOC 38781c).

Etymology. Specific name is in honor of Dr. Lauro Travassos from the Instituto Oswaldo Cruz, FIOCRUZ, Brazil, for his great contribution to the knowledge of Brazilian helminth biodiversity. 


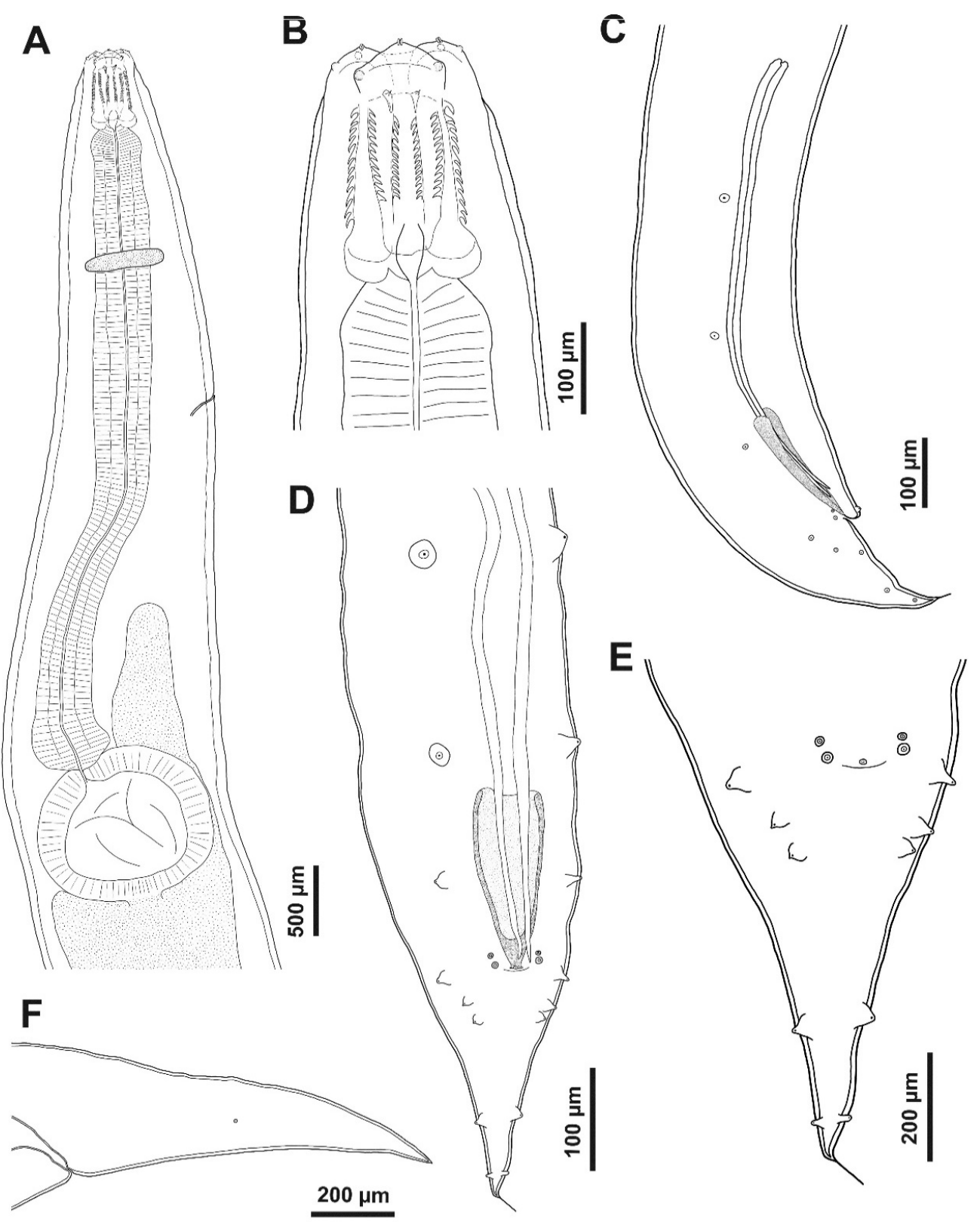

Figure 1. Cruzia lauroi sp. nov. (A) anterior region of body, male, lateral view; (B) cephalic end, male, lateral view; (C) posterior region, male, lateral view; (D) posterior region, male, latero-ventral view; (E) tail, male, latero-ventral view; (F) tail, female, lateral view.

\section{Discussion}

The new species was assigned to the genus Cruzia because of the following morphological characteristics. The anterior end shows an oral aperture surrounded by three lips: on the dorsal lip, there is a pair of lateral papillae; and on the latero-ventral lips, one lateral papilla on each. There is one pair of tooth like structures located at the inner margin of each lip. The pharynx shows three columns with small tooth like structures, like a saw, which projects inwards and into the lumen. The intestinal diverticulum is prominent: it projects anteriorly and goes beyond the esophageal bulb. In males, the caudal region presents symmetrically located sessile papillae, a triangular gubernaculum and two spicules that are similar to each other and do not have a cloacal sucker. 
Currently, nine species of Cruzia are considered to be valid (Table 1): six have been described from mammal hosts, two are parasitic in reptiles and one occurs in amphibians (Sprehn, 1932; Ruiz, 1947; Wolfgang, 1951; Crites, 1956; Wahid, 1964; Costa, 1965; Ubelaker \& Younus, 1965; Guerrero, 1971; Adnet et al., 2009).

In different species of Cruzia, the number of teeth per row in the inner pharynx may be the main characteristic enabling species differentiation. Cruzia lauroi sp. nov. has 12 teeth in each row in the pharynx, which differs from C. buckleyi Wahid, 1964, and C. empera Guerrero, 1971, which have fewer teeth per row (Wahid, 1964; Guerrero, 1971). It also differs from C. americana Maplestone, 1930, C. boliviana Sprehn, 1932, C. brasiliensis Costa, 1965, and C. rudolphii Ruiz, 1947, which have considerably greater numbers of teeth per row than does Cruzia lauroi sp. nov. (Sprehn, 1932; Ruiz, 1947; Crites, 1956; Costa, 1965) (Table 1).

Cruzia cameroni Wolfgang, 1951, C. tentaculata (Rudolphi, 1819) and C. tropidodipsi Ubelaker \& Younus, 1965, present variation in the number of teeth per row of the pharynx that is close to that of Cruzia lauroi sp. nov. (Wolfgang, 1951; Ubelaker \& Younus, 1965; Adnet et al., 2009) (Table 1). However, Cruzia lauroi sp. nov. differs from C. cameroni and C. tropidodipsi in that these last two species do not have an unpaired papilla on the anterior border of the cloacal lip; and in relation to the position of the vulva, which in Cruzia lauroi sp. nov. is pre-cloacal (Table 1).

The species of the genus Cruzia in which the set of morphological and morphometric characteristics is closest to those of Cruzia lauroi sp. nov. is C. tentaculata (Rudolphi, 1819) (Table 1), which occurs mainly in mammals of the family Didelphidae (Travassos, 1917, 1922; Ruiz, 1947; Adnet et al., 2009). The latter species has also been recorded in Tupinambis teguixin (Linnaeus, 1758) (Squamata; Teiidae), and Rhinella marina (Linnaeus, 1758) (Anura; Bufonidae) (Ruiz, 1947).

Cruzia lauroi sp. nov. differs from $C$. tentaculata in that the individuals of the new species have shorter body length, higher number of toothlike structures per row of the pharynx, greater size of diverticulum in comparison with the size of the esophagus, smaller absolute size of spicules and a more anterior vulva than in C. tentaculata; and the males do not have caudal alae (Table 2). 
Table 1. Species of Cruzia Travassos, 1917, taxonomic characters of species, type hosts and localities of species.

\begin{tabular}{|c|c|c|c|c|c|c|c|c|c|}
\hline \multirow[b]{3}{*}{ Cruzia spp. } & \multicolumn{6}{|c|}{ Characters } & \multirow[b]{3}{*}{ Type host } & \multirow[b]{3}{*}{ Country } & \multirow[b]{3}{*}{ References } \\
\hline & \multicolumn{5}{|c|}{ Male } & \multirow{2}{*}{$\begin{array}{c}\text { Female } \\
\text { Vulva position }\end{array}$} & & & \\
\hline & $\begin{array}{l}\text { Number of } \\
\text { tooth-like } \\
\text { structures }\end{array}$ & $\begin{array}{l}\text { Spicule } \\
(\mu \mathrm{m})\end{array}$ & $\begin{array}{l}\text { Gubernaculum } \\
\qquad(\mu \mathrm{m})\end{array}$ & $\begin{array}{l}\text { Caudal papillae } \\
\text { pre: ad: } \\
\text { postcloacal }\end{array}$ & $\begin{array}{l}\text { Unpaired } \\
\text { Papillae }\end{array}$ & & & & \\
\hline $\begin{array}{l}\text { Cruzia americana } \\
\text { Maplestone, } 1930\end{array}$ & $15-18$ & $890-1000$ & $140-160$ & $3: 3: 5$ & No & Pre- equatorial & $\begin{array}{l}\text { Didelphis marsupialis } \\
\text { (Mammal) }\end{array}$ & USA & Crites (1956) \\
\hline $\begin{array}{l}\text { Cruzia boliviana } \\
\text { Sprehn, } 1932\end{array}$ & $16-18$ & 880 & 180 & $3: 3: 4$ & Yes & Pre- equatorial & $\begin{array}{c}\text { Tolypeutes matacus (= } T \text {. } \\
\text { conurus) and Dasypus } \\
\text { novemcinctus } \\
\text { (=T. novemcintus) } \\
\text { (Mammal) }\end{array}$ & $\begin{array}{l}\text { Paraguay and } \\
\text { Bolivia }\end{array}$ & Sprehn (1932) \\
\hline $\begin{array}{l}\text { Cruzia brasiliensis } \\
\text { Costa, } 1965\end{array}$ & $17-22$ & 848 & 219 & $3: 3: 5$ & Yes & Equatorial & Sus scrofa (Mammal) & Brazil & Costa (1965) \\
\hline $\begin{array}{l}\text { Cruzia buckleyi } \\
\text { Wahid, } 1964\end{array}$ & $6-7$ & $1500-1700$ & 260 & $3: 2: 4$ & Yes & Post-equatorial & Callimico goeldii (Mammal) & South America* & Wahid (1964) \\
\hline $\begin{array}{l}\text { Cruzia cameroni } \\
\text { Wolfgang, } 1951\end{array}$ & $13-17$ & $1170-1270$ & 180-195 & 3:3:4 & No & Equatorial & $\begin{array}{l}\text { Didelphis marsupialis } \\
\text { (Mammal) }\end{array}$ & Trinidad & Wolfgang (1951) \\
\hline $\begin{array}{l}\text { Cruzia empera } \\
\text { Guerrero, } 1971\end{array}$ & 9 & $697-737$ & $123-131$ & $3: 3: 4$ & No & Equatorial & $\begin{array}{l}\text { Rhinella marina ( }=\text { Bufo } \\
\text { marinus) (frog) }\end{array}$ & Venezuela & Guerrero (1971) \\
\hline Cruzia lauroi sp. nov. & 12 & $600-750$ & $130-180$ & $3: 3: 4$ & Yes & Pre-equatorial & $\begin{array}{l}\text { Salvator merianae } \\
\text { (Lizard) }\end{array}$ & Brazil & Current study \\
\hline $\begin{array}{l}\text { Cruzia rudolphi } \\
\text { Ruiz, } 1947\end{array}$ & $16-18$ & 490 & 130 & $3: 3: 4$ & Yes & Equatorial & $\begin{array}{c}\text { Erythrolamprus aesculapii } \\
\text { (Snake) }\end{array}$ & Brazil & Ruiz (1947) \\
\hline $\begin{array}{l}\text { Cruzia tentaculata } \\
\text { (Rudolphi, 1819) }\end{array}$ & 10 & $890-960$ & $160-190$ & $3: 3: 4$ & Yes & Pre- equatorial & Didelphis aurita (Mammal) & Brazil & $\begin{array}{l}\text { Adnet et al. } \\
\text { (2009) }\end{array}$ \\
\hline $\begin{array}{l}\text { Cruzia tropidodipsi } \\
\text { Ubelaker and Younus, } 1965\end{array}$ & $13-14$ & $760-1210$ & 150 & $3: 3: 4$ & No & $\begin{array}{c}\text { Post- } \\
\text { equatorial }\end{array}$ & $\begin{array}{c}\text { Tropidodipsas fasciata } \\
\text { (Snake) }\end{array}$ & Mexico & $\begin{array}{c}\text { Ubelaker \& } \\
\text { Younus (1965) } \\
\end{array}$ \\
\hline
\end{tabular}

*Host from an unnamed country in South America, and inhabiting the Zoological Garden of London, UK. 
Table 2. Comparative morphometrics of Cruzia lauroi sp. nov.and Cruzia tentaculata (Rudolphi, 1819).

\begin{tabular}{|c|c|c|c|c|}
\hline & \multicolumn{2}{|c|}{ Cruzia lauroi sp. nov. } & \multicolumn{2}{|c|}{ Cruzia tentaculata (Rudolphi, 1819) } \\
\hline Hosts & \multicolumn{2}{|c|}{ Salvator merianae (Duméril \& Bibron, 1839) } & \multicolumn{2}{|c|}{ Didelphis aurita (Wied-Neuwied, 1826), D. marsupialis Linnaeus, 1758} \\
\hline References & \multicolumn{2}{|c|}{ Current study } & \multicolumn{2}{|c|}{ Adnet et al. (2009) } \\
\hline \multirow[t]{2}{*}{ Localities } & \multicolumn{2}{|c|}{ Brazil } & \multicolumn{2}{|c|}{ Brazil, Colombia } \\
\hline & Females & Males & Females & Males \\
\hline Body length (mm) & $8.21-9.75$ & $6.60-8.82$ & $11.40-12.20$ & $11-12.05$ \\
\hline Body width & $370-450$ & $330-410$ & $500-550$ & $530-650$ \\
\hline Pharynx length & $140-200$ & $90-150$ & $170-260$ & $170-210$ \\
\hline $\begin{array}{l}\text { Number of tooth-like } \\
\text { structures in each row }\end{array}$ & 12 & 12 & 10 & 10 \\
\hline Oesophagus length (mm) & $1.56-2$ & $1.31-1.95$ & $1.59-2.16$ & $2.07-2.32$ \\
\hline Oesophagus width & $120-150$ & $80-95$ & $90-140$ & $100-130$ \\
\hline Oesophagus bulb length & $270-330$ & $200-310$ & $250-270$ & $290-320$ \\
\hline Oesophagus bulb width & $280-330$ & $200-300$ & $250-320$ & $270-330$ \\
\hline Nerve ring & $260-420$ & $260-480$ & $480-550$ & $480-550$ \\
\hline Excretory pore & 920 & $770-930$ & $1180-1300$ & $1180-1300$ \\
\hline Diverticulum length & $470-980$ & $550-850$ & $390-450$ & $370-420$ \\
\hline Diverticulum - oesophagus ratio & $40 \%$ & $42 \%$ & $20 \%$ & $18 \%$ \\
\hline Spicule length & & $600-750$ & & $890-960$ \\
\hline Gubernaculum length & & $130-180$ & & $160-190$ \\
\hline Number and position of caudal papillae & & $\begin{array}{c}10 \text { pairs } \\
(3 \text { pre }+3 \text { ad }+4 \text { post })+1 \\
\text { unpaired }\end{array}$ & & $\begin{array}{c}10 \text { pairs } \\
(3 \text { pre }+3 \text { ad }+4 \text { post })+1 \\
\text { unpaired }\end{array}$ \\
\hline Vulva from anterior end (mm) & $\begin{array}{c}1.71-2.17 \\
\text { (Pre equatorial) }\end{array}$ & & $\begin{array}{c}5.54-5.83 \\
\text { (Pre equatorial) }\end{array}$ & \\
\hline Vulva - body length ratio & $21 \%$ & & $48 \%$ & \\
\hline Egg length & - & & $100-130$ & \\
\hline Egg width & - & & 60 & \\
\hline Tail & $610-920$ & $140-250$ & $690-1040$ & $150-180$ \\
\hline
\end{tabular}


The most recent identification key for species of Cruzia was drafted by Ruiz (1947). However, some species were proposed after that study (C. brasiliensis, C. buckleyi, C. cameroni, C. empera and C. tropidodipsi); or were included in other genera, as was the case of Pseudocruzia orientalis (Maplestone, 1931), which was originally described as C. orientalis and was transferred to Pseudocruzia by Wolfgang (1953), and Schizobucca fulleborni (Khalil and Vogelsang, 1931), which was originally described as C. fulleborni and was transferred to Schizobucca by Schuurmans-Stekhoven Jr. (1950). Chabaud (1978) considered that the genera Schizobucca and Pseudocruzia were valid. Therefore, we present here the latest key to identification of valid species of Cruzia.

\section{Key to species of Cruzia}

1. Male with less than 15 tooth-like structures in each columns of pharynx .............. 2

- Male with 15 or more tooth-like structures in each columns of pharynx ................... 6

2. Absence of unpaired papilla on the anterior border of the cloaca ........................... 3

- Presence of unpaired papilla on the anterior border of the cloaca ........................... 4

3. Spicules greater than $900 \mu \mathrm{m}$.................................. Cruzia cameroni Wolfgang, 1951

- Spicules shorter than $900 \mu \mathrm{m}$........................................ Cruzia empera Guerrero, 1971

4. Vulva pre-equatorial ................................................................................................. 5

- Vulva post-equatorial ........................................................ Cruzia buckleyi Wahid, 1964

5. Male without caudal alae. Spicules shorter than $800 \mu \mathrm{m}$. Twelve tooth-like structures in each columns of pharynx ............................................... Cruzia lauroi sp. nov.

- Male with small caudal alae. Spicules larger than $800 \mu \mathrm{m}$. Ten tooth-like structures in each columns of pharynx Cruzia tentaculata (Rudolphi, 1819)

6. Presence of unpaired papilla on the anterior border of the cloaca .......................... 7

- Absence of unpaired papilla on the anterior border of the cloaca ............................... 8

7. Eleven pair of caudal papillae. Vulva pre-equatorial

- Ten pair of caudal papillae. Vulva post-equatorial

Cruzia americana Maplestone, 1930

Cruzia tropidodipsi Ubelaker and Younus, 1965

8. Spicules greater than $600 \mu \mathrm{m}$

- Spicules shorter than $600 \mu \mathrm{m}$

Cruzia rudolphi Ruiz, 1947

9. Eleven pair of caudal papillae Cruzia brasiliensis Costa, 1965

- Ten pair of caudal papillae Cruzia boliviana Sprehn, 1932

Only a few species of Cruzia have been reported from reptiles in South America (Ávila et al., 2010). Moreover, most of these records do not detail any morphological or morphometric characteristics of the parasites, which leaves doubt regarding their identification. Cruzia tentaculata was reported parasitizing T. teguixin in Uruguay but Lent \& Freitas (1948) did not provide any taxonomic description of this species. The same situation occurred in relation to the records of C. travassosia in S. merianae from the Cerrado biome in Brazil, which was studied by Ávila et al. (2010); and in relation to C. rudolphii from Hoplocercus spinosus Fitzinger, 1843 (Squamata; Hoplocercidae) in the Brazilian Cerrado (Ávila et al., 2008). The study by Ruiz (1947) is the only one that has provided detailed taxonomic descriptions of the species of Cruzia parasitizing Brazilian hosts, including C. rudolphii, which is a parasite of Erythrolamprus aesculapii (Linnaeus, 1758) (Squamata; Colubridae) in Brazil. Therefore, it can be stated that further taxonomic studies on species of Cruzia in Brazilian reptiles are necessary, in order to understand the real dimensions of the biodiversity of the species of this genus in Brazilian reptiles.

Other species previously assigned to Cruzia deserve some comments. C. mazza and C. travassosia, which were found in mammals of the genus Tolypeutes Illiger, 1811 (Cingulata; Dasypodidae), in Argentina, are poorly described, because the number of 
tooth like structures is unknown, the description needs more graphic representation of taxonomic structures, the information about type material is non-existent and further details on the type locality were not reported (Khalil \& Vogelsang, 1932). In relation to Cruzia mexicana, a parasite from an unspecified species of lizard in Mexico, the number of tooth like structures in the pharynx was not informed and the information about type material is non-existent (Khalil, 1927). Cruzia testudinis, which occurs in Terrapene carolina (Linnaeus, 1758) (Testudines, Emydidae) in the USA, was poorly described, since the number of tooth like structures in the pharynx is unknown and the graphical representation of the species is non-existent (Hardwood, 1932). Therefore, we prefer to consider these species as species inquirendae.

\section{Acknowledgements}

This study was financed in part by the Coordenação de Aperfeiçoamento de Pessoal de Nível Superior - Brazil (CAPES) - Finance Code 001. Fabiano M. Vieira was supported by a Postdoctoral fellowship from Programa Nacional de Pós-doutorado (PNPD), Coordenação de Aperfeiçoamento de Pessoal de Nível Superior, Brasil/Fundação Instituto Oswaldo Cruz (CAPES/FIOCRUZ) at the Programa de Pós-graduação em Biodiversidade e Saúde (PPGBS) of the Instituto Oswaldo Cruz (IOC), Rio de Janeiro, RJ, Brazil. Bernadete M. Sousa was supported by Productivity fellowship by Conselho Nacional de Desenvolvimento Científico e Tecnológico, Brazil (CNPq).

\section{References}

Adnet FAO, Anjos DHS, Menezes-Oliveira A, Lanfredi RM. Further description of Cruzia tentaculata (Rudolphi, 1819) Travassos, 1917 (Nematoda: Cruzidae) by light and scanning electron microscopy. Parasitol Res 2009; 104(5): 1207-1211. http://dx.doi.org/10.1007/s00436-008-1316-6. PMid:19130086.

Ávila RW, Cáceres NC, Ferreira VL, Silva RJ. Hoplocercus spinosus (NCN). Endoparasites. Herp Rev 2008; 39(1): 88-89.

Ávila RW, Silva RJ. Checklist of helminths from lizards and amphisbaenians (Reptilia, Squamata) of South America.J Venom Anim Toxins Incl Trop Dis 2010; 16(4): 543-572. http://dx.doi.org/10.1590/S1678-91992010000400005.

Ávila RW, Souza FL, Silva RJ. Helminths from seven species of lizards (Reptilia: Squamata) at the Cerrado of Mato Grosso do Sul State, Brazil. Comp Parasitol 2010; 77(1): 67-71. http://dx.doi.org/10.1654/4414.1.

Baker MR. Synopsis of the Nematoda parasitic in amphibians and reptiles. Mem Univ Newfoundland Occ Pap Biol 1987; 11: 1-325.

Chabaud AG. Keys to the genera of the superfamilies Cosmocercoidea, Seuratoidea, Heterakoidea and Subuluroidea. In: Anderson RC, Chabaud AG, Willmott S. CIH Keys to the nematode parasites of vertebrates. England: Commomwealth Agricultural Bureaux; 1978. p. 1-71.

Costa HM. Cruzia brasiliensis n. sp. (Nematoda-Cruziidae) parasita de Sus domesticus. Arq Esc Vet 1965; 17: 61-69.

Crites JL. A redescription of Cruzia americana, a nematode parasitic in the opossum, Didelphis marsupialis virginiana. J Parasitol 1956; 42(1): 68-72. http://dx.doi.org/10.2307/3274625. PMid:13295896.

Guerrero R. Helmintos de la Hacienda “El Limón”, D.F, Venezuela. Nematodes de Vertebrados I. Mem Soc Cienc Nat La Salle 1971; 31: 175-230.

Hardwood PD. The helminths parasitic in the Amphibia and Reptilia of Houston, Texas, and Vicinity. Proc U S Nat Mus 1932; 81(2940): 1-71. https://doi.org/10.5479/si.00963801.81-2940.1.

Khalil M, Vogelsang EG. On some nematode parasites from South American Animals. Zentralb/ Bakt I Abt Orig 1932; 123: 477-485.

Khalil M. Cruzia mexicana n. sp. parasite d'un lézard mexicain. Ann Parasitol Hum Comp 1927; 5(1): 41 46. http://dx.doi.org/10.1051/parasite/1927051041. 
Lent H, Freitas JFT. Uma coleção de nematódeos, parasitos de vertebrados, do Museu de Historia Natural de Montevideo. Mem Inst Oswaldo Cruz 1948; 46(1): 1-71. http://dx.doi.org/10.1590/S0074-02761948000100001.

Peters AJ, Donoso-Barros R, Orejas-Miranda B. Catalogue of neotropical squamata Part I: Snakes - Part II: Lizards and amphisbaenians with new material by P. E. Vanzolini. Washington: Smithsonian Institution Press; 1986.

Ruiz JM. Revisão do gênero Cruzia (Nematoda: Oxyuroidea) e estudo das espécies brasileiras. [Tese]. São Paulo: Faculdade de Farmácia e Odontologia da USP; 1947.

Schuurmans-Stekhoven JH Jr. Nematodos parasitarios del Chaco Paraguayo y de Argentina del Museo de Estocolmo. Acta Zool Lilloana 1950; 9: 325-345.

Sprehn VC. Uber einig von Dr. Eisentraut in Bolivia gesamelte Nematode. Zool Anz 1932; 100: 273284.

Travassos L. Alguns helmintos da coleção do Instituto bacteriológico de São Paulo. Braz Med 1917; 31: 99-100.

Travassos L. Contribuições para o conhecimento da fauna helmintolojica brasileira-XVI. Cruzia tentaculata (Rud., 1819). Mem Inst Oswaldo Cruz 1922; 14(1): 88-94. http://dx.doi.org/10.1590/S0074-02761922000100004.

Ubelaker JE, Younus M. A new nematode, Cruzia tropidodipsi, parasitic in the snake Tropidodipsas fasciata. Trans Kans Acad Sci 1965; 68(1): 194-197. http://dx.doi.org/10.2307/3626364.

Wahid S. On the genus Cruzia Travassos, 1917 with a description of a new species C. buckleyi from a primate, Callimico goeldii. J Helminthol 1964; 38(1-2): 175-180. http://dx.doi.org/10.1017/S0022149X00033721.

Wolfgang RW. Studies on the endoparasitic fauna of Trinidad mammals: VIII. Parasites of Marsupialis. Can J Zool 1951; 29(6): 352-373. http://dx.doi.org/10.1139/z51-031. 